\title{
Carp Seed Production in FRP Hatcheries by Tribal Farmers of Ganjam District, Odisha, India
}

\author{
B. C. Mohapatra ${ }^{1}$, N. K. Moharana ${ }^{2}$, D. Majhi ${ }^{1}$, A. D. Sahu ${ }^{1}$, \\ M. Mahapatra ${ }^{1}$ and S. P. Bhoi ${ }^{2}$ \\ ${ }^{1}$ ICAR-Central Institute of Freshwater Aquaculture, \\ Kausalyaganga, Bhubaneswar - 751002, Odisha, India \\ ${ }^{2}$ District Fisheries Office, Ganjam (Zone), Berhampur, Odisha, India \\ *Corresponding author
}

\section{Keywords}

FRP carp hatchery, Induced breeding, Spawn production, Tribal beneficiaries, Ganjam District

\section{Article Info}

Accepted:

21 May 2020

Available Online:

10 June 2020

\begin{abstract}
A B S T R A C T
Induced breeding is a technique to stimulate ripe fish breeders by different inducing agents to breed in captive condition. Four fiberglass reinforced plastic (FRP) carp hatchery units (technology developed by ICAR-CIFA) were supplied, installed and operated in cyclone, Phailin-affected four adopted villages, namely Ambapur and Sindhukhalli in Digapahandi Block, Sujanasahi in Khallikote Block and Daseipur in Sanakhemundi Block of Ganjam District, Odisha for carp seed production. In the established hatchery units induced breeding of Indian major carp, rohu (Labeo rohita) was successfully conducted by synthetic hormone 'Ovatide' in the monsoons of 2018 and 2019. Induced breeding programmes were conducted for two times at Ambapur Village and four times at Sindhukhali Village in 2018; and four times at Ambapur Village, five times at Sindhukhali Village, three times at Sujanasahi Village and one time at Daseipur Village in 2019. Total 21 lakh rohu spawn (7.5 lakh in Ambapur and 13.5 lakh in Sindhukhali) and 121 lakh (41 lakh in Ambapur, 49 lakh in Sindhukhali, 27.5 lakh in Sujanasahi and 3.5 lakh in Daseipur) was harvested in 2018 and 2019, respectively. Spawning was observed after a latency period of 330-420 minutes; fertilization rate was $84.5-95.0 \%$ under the temperature range of $26.5-33.2{ }^{\circ} \mathrm{C}$ and spawn production was $0.78-1.16 \mathrm{lakh} / \mathrm{kg}$ body wt. of female rohu in the field conditions.
\end{abstract}

\section{Introduction}

Aquaculture is the booming sector in India providing livelihood to millions of farmers, poverty alleviation and economic development of the poor. The role of aquaculture in providing the much-needed animal protein to the world population is well documented (FAO, 2016). Recognized as a powerful income and employment generator, aquaculture stimulates growth of a number of subsidiary industries and is a source of cheap and nutritious food, besides being a foreign exchange earner.

Good quality fish seed is the prime and basic need for aquaculture production. Fish seed produced in natural sources of spawning possess uncertainty in availability, quality, mixing of unwanted fish seeds. 
The induced breeding of carps in hatcheries helped in production of quality seed under controlled condition and assured supply of stocking material in right time for aquaculture farms. The contributions of several workers starting from hapa breeding to cemented ecohatchery, and then to portable FRP hatchery have made availability of fish seed easy for aqua-farming. All India Coordinated Research Project on Plasticulture Engineering and Technology (AICRP on PET) Centre at ICAR-CIFA, Bhubaneswar has designed and developed portable fiberglass reinforced plastic (FRP) carp hatchery for the benefit of marginal fish farmers of India (Mohapatra et al., 2003 and 2005).

In the developed FRP carp hatchery in one operation 10-12 kg of female carps and equal quantity of males can be taken for induced breeding programme. In one run, 1.0-1.2 million spawn can be produced from the hatchery, which is sufficient to produce fingerlings for stocking in grow-out ponds of about 30 hectares with stocking density @ 5,000 fingerlings/ha (Mohapatra et al., 2017).

Ganjam District of Odisha State is in 19.4 to 20.17 degree North Latitude and 84.7 to 85.12 degree East Longitude. It covers an area of 8070.60 sq.km. The district experiences normal annual rainfall of $1,444 \mathrm{~mm}$. Agriculture is traditional and main occupation of the inhabitants of the district. Ganjam is considered to be one of the potential aquaculture resources districts of the state in the form of freshwater ponds 11580.0 ha, brackish water 4023.04 ha and for marine fisheries has $60 \mathrm{~km}$ coastline.

These resources are very much suitable for pond culture, reservoir fisheries and shrimp culture purposes. It can provide an excellent opportunity to develop pisciculture for increasing fish production, thus, to meet the growing demand of the people as well as play a significant role for providing employment opportunity to the rural poor. The main factor of rural development is to utilize productively the available resources in local areas. The ponds, tanks and small reservoirs available in villages are often remain unutilized and underutilized due to various reasons, such as, lack of technical knowledge, lack of investment and support for inputs, marketing system, etc. In most of the villages, available water bodies are owned, controlled and managed by the village development communities (VDC) or self-help groups (SHG) or panchayats, and the benefits from aquaculture are shared among the community members (Mohapatra and Barik, 2018a).

Hence, sustained efforts are needed to transfer many aquaculture technologies to a large number of farmers for visible impact (Mohapatra and Barik, 2018b). Here the study was focused on socio-economic development of tribal communities of four adopted villages, namely Ambapur and Sindhukhali in Digapahandi Block; Daseipur in Sanakhemundi Block; and Sujanasahi in Khallikote Block of Ganjam District, Odisha and one proven technology developed by ICAR-CIFA i.e., FRP carp hatchery for quality seed production was demonstrated to the farmers of the area.

The study was conducted under the Department of Science and Technology (DST), Govt. of India sponsored project for that area during 2017-20. The tribal farmers of the area were educated on various aspects of brood fish management, carp seed production, FRP hatchery operation and seed rearing up to the size for stocking in grow-out ponds in their areas.

During the study period, the water bodies of the area were examined and feasibility of their utility for carp seed production was also found out by regular visits of the team. 


\section{Materials and Methods}

\section{Study area}

The present work was carried out infour adopted villages, namely Ambapur and Sindhukhali in Digapahandi Block; Daseipur in Sanakhemundi Block; and Sujanasahi in Khallikote Block of Ganjam District, Odisha. The location of blocks in the district map is shown in Figure 1. Total 156 (SC-9, ST-118, OBC-28, General-1) beneficiaries having 10.2 ha pond (14 nos) area were adopted in the study. Total 5 Self Help Groups, namely Maa Grama Devati SHG and Maa Bankeswari $S H G$ in Ambapur Village; Maa Matiapalli Mahila Swayam Sahayak Sangha in Sindhukhali Village; Maa Chandeswari Primary Fisheries Development Union in Sujanasahi Village and Maa Behera Patra $S H G$ in Daseipur Village were engaged in the study. Most of the farmers are under educated and their primary occupation is paddy cultivation, bamboo craft work and daily wages. Their average annual family income varies between INR 26,000 and INR 35,000.

\section{FRP hatchery unit}

Portable fiberglass reinforced plastic (FRP) carp hatchery unit of production capacity 1.01.2 million spawn per operation in four days consisting of four parts i.e., spawning pool, incubation pool, egg/spawn collection tank and overhead water storage tank of capacity 2,000 litter was installed and operated in each adopted village. Thus, four FRP hatchery units were supplied to the district in the monsoons of 2018 and 2019.

\section{Brood stock}

Matured brood stocks of Indian major carp, viz., rohu (Labeo rohita) free from diseases and any kind of abnormalities were selected for the breeding programmes from the brood stock-cum-grow-out ponds of the villages. The brood fishes were reared as per available scientific practices and selection of the broods for breeding operations were done based on their maturity and weight.

\section{Inducing agent}

'Ovatide', an indigenous, cost-effective hormonal formulation developed by Mumbaibased pharmaceutical company, M/s Hemmo Pharma was used for the breeding programmes. Ovatide has been successfully tested for ovulation of several fishes, including Labeo rohita, Labeo calbasu, Cirrhinus mrigala, Catla catla and Clarias batrachus in India (CIFE, 1997). The Ovatide is easy to store at room temperature, simple to use and less expensive.

\section{Breeding programme}

Four FRP carp hatchery units were operated in Digapahandi, Sanakhemundi and Khallikote Blocks of Ganjam District in JulyAugust of 2018 and 2019. Hatchery operations were followed as per the guidelines given by Mohapatra et al., (2017). Brooders sexes were identified based on morphological characters like swollen abdomen, pinkish vent and smooth pectoral fin in female; and rough pectoral fin in male. The brooders were carefully transferred from ponds to the FRP hatchery avoiding much handling and conditioned for one hour in the spawning pool prior to administration of inducing agent. Male brooders were injected with Ovatide @ $0.2 \mathrm{ml} / \mathrm{kg}$ and female brooders $0.5 \mathrm{ml} / \mathrm{kg}$ body weight, intraperitoneally in a single dose. The injected fishes were released in the spawning pool for egg laying. The brood fishes were removed from the breeding/spawning pool with the help of a scoop net after spawning. Water circulation was maintained as per recommendations of Mohanty et al., (2009) 
and Mohapatra et al., (2017). The fertilized eggs were kept in the incubation pool for the next 72 hrs. The breeding/spawning pool was disinfected by sprinkling $5.0 \mathrm{ppm}$ potassium permanganate solution at an interval of two hours.

$\%$ of fertilization per female was calculated with the following formula:

$$
\text { Fertilization }=\frac{\text { No. of fertilized eggs }}{\text { Total No. of egg counted }} \times 100
$$

Latency period (time from injection to egg release), effective spawning period (time from first egg release to the end of egg release), hatching time, total spawn production per operation and spawn production per $\mathrm{kg}$ body weight of female fish were determined.

\section{Water quality parameters}

The water quality parameters of the pond (inlet water to hatchery unit) were analysed as per standard laboratory procedures bringing water samples to ICAR- CIFA. The physicochemical parameters studied were water temperature $\left({ }^{\circ} \mathrm{C}\right)$, dissolved oxygen $(\mathrm{mg} / \mathrm{l})$, $\mathrm{pH}$, total alkalinity $(\mathrm{mg} / \mathrm{l})$, total hardness $(\mathrm{mg} / \mathrm{l})$ and water transparency $(\mathrm{cm})$ in every hatchery operation period by standard laboratory procedures of APHA (1989).

\section{Results and Discussion}

\section{Carp breeding operation}

Fiberglass reinforced plastic (FRP) hatchery units were established in farmer's field at Ambapur and Sindhukhalli Villages under Digapahandi Block; Sujanasahi Village under Khallikote Block and Daseipur Village under Sanakhemundi Block, Ganjam District. Rohu, L.rohita as test fish with single injection of Ovatide was successfully induced to spawn in established FRP carp hatchery units during monsoons of 2018 and 2019. Ovatide is the cheaper hormone and $70 \%$ more economical as compared to Ovaprim (Bhatti and Qureshi, 2000). The Ovatide suppresses the Ovaprim use giving an equal result of seed production in hatcheries. Pandey et al., (2002) found the fertilization rate of $95-100 \%$ and hatching success $90-98 \%$ in $L$. rohita at a water temperature of $28-31^{\circ} \mathrm{C}$ using hormone Ovatide. Dhawan and Kaur (2004) used Ovatide and Ovaprim for induced breeding of Indian carps. They found that Ovaprim was more effective than Ovatide in breeding induction in C. catla; however, in L. rohita and $C$. mrigala, Ovatide resulted in high fecundity and fertilization rate. Khan et al., (2006) stated that Ovatide was better than Ovaprim- $C$ in induced spawning, fecundity, hatching and fertilization of L. rohita. Effective spawning period of catla was calculated to be 53.3 minutes, rohu 62 minutes and mrigala 40 minutes.

Results of the breeding trials are summarized in Tables 1 and 2. Total 21 lakh (7.5 lakh Ambapur Village and 13.5 lakh Sindhukhali Village) and 121 lakh (41 lakh Ambapur Village, 49 lakh Sindhukhali Village, 27.5 lakh Sujanasahi Village and 3.5 lakh Daseipur Village) rohu spawn was harvested in 2018 and 2019, respectively. In the monsoon of 2018, two FRP carp hatchery units were operated for two and four times in Ambapur and Sindhukhali Villages, respectively.

Similarly in the monsoon of 2019, four FRP carp hatchery units were operated for four, five, three and one times in Ambapur, Sindhukhali, Sujanasahi and Daseipur Villages, respectively. The fertilization rate was recorded $85-95 \%$ in monsoon of 2018 in two villages and $84.5-95 \%$ in monsoon of 2019 in four village sites. In two monsoons, highest fertilization rate $95 \%$ of rohu was recorded in Ambapur and Sindhukhali Village. 
Time duration 690-895 minutes for completion of egg hatching was recorded in these experiments. In 2018 spawn production was $0.9 \mathrm{lakh} / \mathrm{kg}$ female body weights for Sindhukhali Village and 0.892 lakh/kg female body weights for Ambapur Village. In 2019 highest spawn production was 1.14 lakh/kg female body weights for Sujanasahi Village followed by $1.08 \mathrm{lakh} / \mathrm{kg}$ female body weights for Sindhukhali Village, $1.07 \mathrm{lakh} / \mathrm{kg}$ female body weights for Ambapur Village and $1.06 \mathrm{lakh} / \mathrm{kg}$ female body weights for Daseipur Village.

Mohapatra et al., (2016) had conducted induced breeding of IMC in FRP carp hatchery at Puranapradhan Village of Balianta Block, Khordha District, Odisha. During breeding season of 2015 the hatchery was used for induce breeding of Indian major carps (IMC) i.e., rohu and mrigal for 19 times (viz., rohu 11 times and mrigal 8 times). Total 198 lakh spawn was produced (i.e., rohu 125 lakh and mrigal 73 lakh).

Spawning fecundity was found to be 1.3-1.82 and 1.25-1.58 lakh egg/kg female body weight of rohu and mrigal, respectively. Percentage of fertilized eggs during spawning was calculated to be $90-100 \%$ for both species. Spawn production per $\mathrm{kg}$ female body weight was found to be 1.23-1.55 $\mathrm{lakh} / \mathrm{kg}$ for rohu and 1.09-1.4 lakh/ $\mathrm{kg}$ for mrigal and percentage of spawn survival from fertilized egg ranged $90-97.17 \%$ in rohu and $87.3-94.74 \%$ in mrigal.

Similarly the FRP carp hatchery was installed and operated at Subarnapur Village of Gop Block, Puri District, Odisha during monsoon months of 2015 (Mohapatra et al., 2015). Ten trials of induced breeding of three IMC, $L$. rohita (4 times), $C$. catla (4 times) and $C$. mrigala (2 times) were conducted during monsoon season of 2014. A total of 92.0 lakh spawn (carp seed) was produced (rohu 42 lakh, catla 30 lakh and mrigal 20 lakh). Spawning fecundity of rohu, mrigala and catla was found to be 1.43-1.72; 1.41-1.54 and $1.15-1.23$ lakh $\mathrm{egg} / \mathrm{kg}$ female body weight respectively. Percentage of fertilized eggs during spawning was found to be $90-95 \%$. Spawn production per $\mathrm{kg}$ female body weight (lakh) was found $1.07-1.36 \mathrm{lakh} / \mathrm{kg}$ female body weight of rohu, 1.17-1.36 lakh/ $\mathrm{kg}$ female body weight of mrigal and 0.9-0.95 lakh $/ \mathrm{kg}$ female body weight of catla. Further to compare the findings of present study, the study of Chakrabarti et al., (2016) may be taken to consideration.

One unit of FRP carp hatchery was installed and operated at Bali Island, Sunderban, West Bengal during 2014-15. In the hatchery operation, spawning fecundity of rohu was found to be 0.88-1.0 lakh, catla 0.95 lakh and bata 1.1-1.3 lakh egg/kg bodyweight of female fish. Hatching time was found more or less similar in rohu 920-970 minutes, catla 965 minutes and bata 940-990 minutes. Spawn survival percentage from egg release was calculated to be 85.5-92.5 in rohu, 84.5 in catla and $86.5-90$ in bata. Spawn production per $\mathrm{kg}$ female body weight was found similar for all the experimented fishes i.e. rohu 0.740.88 lakh, bata 0.86-1.2 lakh and catla 0.66 lakh.

One FRP carp hatchery was established and operated in farmer's field at N.B. Pokhria Village under Bisoi Block, Mayurbhanj District, Odisha from 4 July, 2016 (Mohapatra et al., 2018c). Induced breedings of Indian major carps (catla, rohu, \& mrigal) were conducted in the established hatchery using synthetic hormone 'Ovatide' for 1, 3 and 6 times in the monsoons of 2016, 2017 and 2018, respectively. Total 7.0 lakh (rohu), 20.0 lakh (rohu 10.0, mrigal 3.0, and catla 7.0) and 48.5 lakh (rohu 28.5, mrigal 5.0, and catla 15.0) lakh spawn was harvested in 2016, 2017 and 2018, respectively showing a 
positive trend as the farmer is getting experienced year after year. Under the temperature range of $27-34^{0} \mathrm{C}$, spawning was observed after a latency period of $342-400$ minutes (5.7-6.7 hours); fertilization rate recorded was $91.7-97.5 \%$ and spawn production was $1.02-1.18 \mathrm{lakh} / \mathrm{kg}$ body wt. of female in IMC. Highest fertilization rate
(97.5\%) was recorded in mrigal followed by rohu (92\%) and catla (91.7\%). Effective spawning period was $62,53.3$ and 40 minutes for rohu, catla and mrigal respectively. The present study was in agreement with the studies conducted by different authors using the FRP carp hatchery for IMC breeding purposes.

Table.1 IMC breeding in FRP carp hatchery at Ambapur and Digapahandi Villages under Digapahandi Block of Ganjam District, Odisha in 2018 monsoon

\begin{tabular}{|c|c|c|c|c|c|c|c|c|}
\hline Block & \multicolumn{8}{|c|}{ Digapahandi } \\
\hline Village & \multicolumn{3}{|c|}{ Ambapur } & \multicolumn{5}{|c|}{ Sindhukhali } \\
\hline Species & \multicolumn{3}{|c|}{ Rohu } & \multicolumn{5}{|c|}{ Rohu } \\
\hline Trials & 1 & 2 & Total $(\mathbf{T}) /$ & 1 & 2 & 3 & 4 & Total $(\mathbf{T}) /$ \\
\hline Year & 2018 & 2018 & (A) & 2018 & 2018 & 2018 & 2018 & (A) \\
\hline Number of male breeders & 3 & 3 & $6(\mathrm{~T})$ & 3 & 4 & 3 & 2 & $12(\mathrm{~T})$ \\
\hline Number of female breeders & 3 & 3 & $6(\mathrm{~T})$ & 3 & 4 & 3 & 2 & $12(\mathrm{~T})$ \\
\hline $\begin{array}{c}\text { Total weight of male breeder } \\
(\mathbf{k g})\end{array}$ & 3.8 & 4.5 & $8.3(\mathrm{~T})$ & 3.9 & 4.5 & 3.8 & 2.5 & $14.7(\mathrm{~T})$ \\
\hline $\begin{array}{c}\text { Total weight of female } \\
\text { breeder (kg) }\end{array}$ & 4 & 4.4 & $8.4(\mathrm{~T})$ & 4 & 4.5 & 3.9 & 2.6 & $15(\mathrm{~T})$ \\
\hline $\begin{array}{l}\text { Time of first egg release } \\
\text { after hormone injection } \\
\text { (min.) (latency period) (A) }\end{array}$ & 360 & 370 & $365(\mathrm{~A})$ & 340 & 330 & 360 & 370 & $350(\mathrm{~A})$ \\
\hline $\begin{array}{l}\text { Completion time of egg } \\
\text { release from time of } \\
\text { injection (in minute) (B) }\end{array}$ & 390 & 405 & $397.5(\mathrm{~A})$ & 400 & 400 & 420 & 410 & $407.5(\mathrm{~A})$ \\
\hline $\begin{array}{l}\text { Effective spawning period } \\
\text { (B-A) (minute) }\end{array}$ & 30 & 35 & $32.5(\mathrm{~A})$ & 60 & 70 & 60 & 40 & $57.5(\mathrm{~A})$ \\
\hline Egg released (lakh approx.) & 4 & 4.5 & $8.5(\mathrm{~T})$ & 4 & 4.8 & 4 & 2.5 & $15.3(\mathrm{~T})$ \\
\hline Fertilization rate of egg (\%) & 90 & 90 & $90(\mathrm{~A})$ & 90 & 95 & 90 & 85 & $90(\mathrm{~A})$ \\
\hline $\begin{array}{l}\text { Time of first hatchling } \\
\text { observed from spawning } \\
\text { (minute) }\end{array}$ & 710 & 690 & $700(\mathrm{~A})$ & 720 & 700 & 740 & 690 & $712.5(\mathrm{~A})$ \\
\hline Spawn recovered (lakh) & 3.5 & 4 & $7.5(\mathrm{~T})$ & 3.5 & 4.5 & 3.5 & 2 & $13.5(\mathrm{~T})$ \\
\hline $\begin{array}{l}\text { Spawn production (lakh/kg } \\
\text { body weight of female) }\end{array}$ & 0.875 & 0.909 & $0.892(\mathrm{~A})$ & 0.875 & 1.0 & 0.897 & 0.78 & $0.9(\mathrm{~A})$ \\
\hline
\end{tabular}


Table.2 IMC breeding in FRP carp hatchery at four villages under Digapahandi, Khallikote and Sanakhemundi Blocks of Ganjam District, Odisha in 2019 monsoon

\begin{tabular}{|c|c|c|c|c|c|c|c|c|c|c|c|c|c|c|c|c|c|}
\hline Block & \multicolumn{11}{|c|}{ Digapahandi } & \multirow{2}{*}{\multicolumn{4}{|c|}{$\begin{array}{l}\text { Khalikote } \\
\text { Sujansahi }\end{array}$}} & \multirow{2}{*}{\multicolumn{2}{|c|}{$\begin{array}{l}\text { Sanakhemundi } \\
\text { Daseipur }\end{array}$}} \\
\hline Village & \multicolumn{6}{|c|}{ Sindhukhali } & \multicolumn{5}{|c|}{ Ambapur } & & & & & & \\
\hline Species & \multicolumn{6}{|c|}{ Rohu } & \multicolumn{5}{|c|}{ Rohu } & \multicolumn{4}{|c|}{ Rohu } & \\
\hline Year & \multicolumn{6}{|c|}{2019} & \multicolumn{5}{|c|}{2019} & \multicolumn{4}{|c|}{2019} & \multicolumn{2}{|c|}{$\begin{array}{l}\text { Rohu } \\
2019\end{array}$} \\
\hline Trials & 1 & 2 & 3 & 4 & 5 & $(\mathrm{~T}) /(\mathrm{A})$ & 1 & 2 & 3 & 4 & $(\mathrm{~T}) /(\mathrm{A})$ & 1 & 2 & 3 & $(\mathrm{~T}) /(\mathrm{A})$ & 1 & $(\mathrm{~T}) /(\mathrm{A})$ \\
\hline Number of male breeders & 6 & 5 & 5 & 7 & 4 & $27(\mathrm{~T})$ & 5 & 6 & 5 & 5 & $21(\mathrm{~T})$ & 5 & 5 & 4 & $14(\mathrm{~T})$ & 3 & $3(\mathrm{~T})$ \\
\hline Number of female breeders & 6 & 5 & 5 & 7 & 4 & $27(\mathrm{~T})$ & 5 & 6 & 5 & 5 & $21(\mathrm{~T})$ & 5 & 5 & 4 & $14(\mathrm{~T})$ & 3 & $3(\mathrm{~T})$ \\
\hline $\begin{array}{l}\text { Total weight of male breeder } \\
\text { (kg) }\end{array}$ & 10.5 & 8 & 10 & 12 & 7.5 & $48(\mathrm{~T})$ & 10 & 12 & 10 & 9.5 & $41.5(\mathrm{~T})$ & 9.2 & 9.5 & 6.3 & $25(\mathrm{~T})$ & 4 & $4(\mathrm{~T})$ \\
\hline $\begin{array}{l}\text { Total weight of female } \\
\text { breeder (kg) }\end{array}$ & 10 & 8 & 9 & 11 & 7 & $45(\mathrm{~T})$ & 10 & 11 & 9 & 8 & $38(\mathrm{~T})$ & 9 & 9 & 6 & $24(\mathrm{~T})$ & 3.3 & $3.3(\mathrm{~T})$ \\
\hline $\begin{array}{l}\text { Time of first egg release after } \\
\text { hormone injection (min.) } \\
\text { (latency period) (A) }\end{array}$ & 360 & 340 & 330 & 360 & 370 & 352 (A) & 370 & 360 & 350 & 365 & $361(\mathrm{~A})$ & 365 & 360 & 370 & $365(\mathrm{~A})$ & 360 & $360(\mathrm{~A})$ \\
\hline $\begin{array}{l}\text { Completion time of egg } \\
\text { release from time of injection } \\
\text { (in minute) (B) }\end{array}$ & 390 & 400 & 400 & 420 & 410 & 404 (A) & 405 & 390 & 390 & 400 & 396 (A) & 410 & 400 & 410 & 407 (A) & 390 & 390 (A) \\
\hline $\begin{array}{l}\text { Effective spawning period (B- } \\
\text { A) (minute) }\end{array}$ & 30 & 60 & 70 & 60 & 40 & $52(\mathrm{~A})$ & 35 & 30 & 40 & 35 & 35 (A) & 45 & 40 & 40 & $42(\mathrm{~A})$ & 30 & $30(\mathrm{~A})$ \\
\hline Egg released (lakh approx.) & 12.5 & 9.5 & 11 & 13 & 8.5 & $54.5(\mathrm{~T})$ & 12 & 13.5 & 10.5 & 9.5 & $45.5(\mathrm{~T})$ & 11.5 & 11 & 7.5 & $30(\mathrm{~T})$ & 4 & $4(\mathrm{~T})$ \\
\hline Fertilization rate of egg $(\%)$ & 92 & 84.5 & 91 & 92.5 & 88.5 & $90(\mathrm{~A})$ & 92 & 85.5 & 90.5 & 95 & $90.5(\mathrm{~A})$ & 91.5 & 91 & 93.5 & $91.5(\mathrm{~A})$ & 87.5 & $87.5(\mathrm{~A})$ \\
\hline $\begin{array}{l}\text { Time of first hatchling } \\
\text { observed from spawning } \\
\text { (minute) }\end{array}$ & 720 & 700 & 740 & 690 & 700 & $710(\mathrm{~A})$ & 710 & 690 & 720 & 700 & $705(\mathrm{~A})$ & 710 & 720 & 690 & $707(\mathrm{~A})$ & 710 & $710(\mathrm{~A})$ \\
\hline Spawn recovered (lakh) & 11.5 & 8 & 10 & 12 & 7.5 & $49(\mathrm{~T})$ & 11 & 11.5 & 9.5 & 9 & $41(\mathrm{~T})$ & 10.5 & 10 & 7 & $27.5(\mathrm{~T})$ & 3.5 & $3.5(\mathrm{~T})$ \\
\hline $\begin{array}{l}\text { Spawn production (lakh/kg } \\
\text { body weight of female) }\end{array}$ & 1.15 & 1 & 1.11 & 1.09 & 1.07 & $1.08(\mathrm{~A})$ & 1.10 & 1.04 & 1.05 & 1.12 & $1.07(\mathrm{~A})$ & 1.16 & 1.11 & 1.16 & $1.14(\mathrm{~A})$ & 1.06 & $1.06(\mathrm{~T})$ \\
\hline
\end{tabular}
$* \mathrm{~T}=$ Total and $\mathrm{A}=$ Average 
Table.3 Physico-chemical properties of hatchery inlet water in Ganjam District

\begin{tabular}{|l|l|l|l|l|}
\hline Water quality parameter & Ambapur & Sindhukhali & Sujanasahi & Daseipur \\
\hline Water temperature $\left({ }^{\circ} \mathbf{C}\right)$ & $29.2-32.6$ & $28.2-31.6$ & $26.5-31.3$ & $26.9-33.2$ \\
\hline Dissolved oxygen $(\mathbf{m g} / \mathbf{l})$ & $3.5-5.3$ & $3.2-5.5$ & $3.4-5.6$ & $3.0-5.5$ \\
\hline pH & $6.60-8.20$ & $6.49-8.48$ & $6.9-7.8$ & $7.21-7.92$ \\
\hline Total alkalinity $(\mathbf{m g} / \mathbf{l})$ & $52-74$ & $67-84$ & $66-87$ & $72-92$ \\
\hline Total hardness $(\mathbf{m g} / \mathbf{l})$ & $57-87$ & $57-85$ & $54-73$ & $75-95$ \\
\hline Water transparency $(\mathbf{c m})$ & $9.5-12.4$ & $7.3-14.47$ & $5.7-12.5$ & $6.5-12.9$ \\
\hline
\end{tabular}

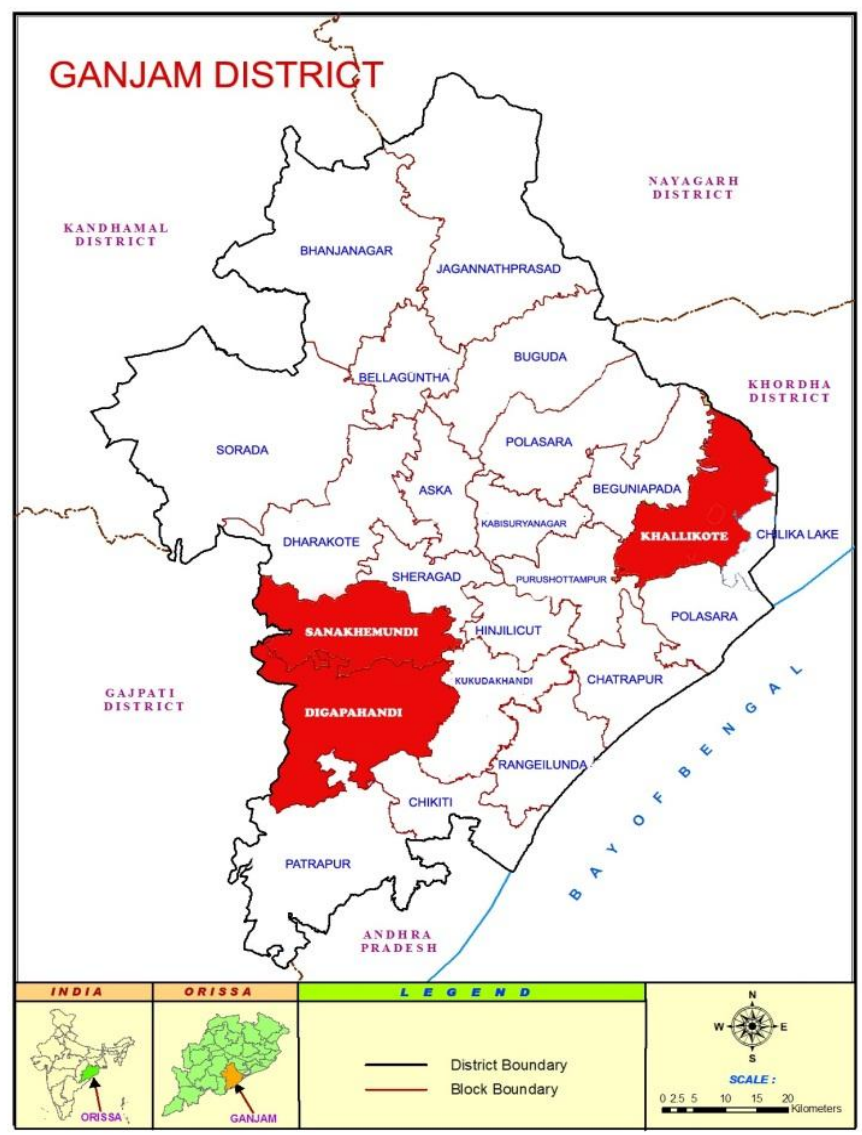

Fig.1 Study area location in Ganjam District

Physico-chemical properties of inlet water to hatchery

Physico-chemical parameters of the inlet water to hatchery from pond during different breeding operations were analysed. The range of water temperatures, $\mathrm{pH}$, dissolved oxygen, total alkalinity, total hardness and transparency were analysed and recorded, and presented in Table 3. The water quality required for hatchery operation for IMC seed production is $24-29{ }^{0} \mathrm{C}$ temperature, $6.5-8.5$ $\mathrm{pH}, 5.0-6.0 \mathrm{mg} / \mathrm{l}$ dissolved oxygen and less than $150 \mathrm{mg} / \mathrm{l}$ total alkalinity (Gupta et al., 2008). The water parameters recorded during the present breeding programmes were found within the range for hatchery operation of IMC. 


\section{Acknowledgement}

The authors acknowledge the financial support from Department of Science and Technology, Government of India for the project operated at ICAR-CIFA and the Director, ICAR-Central Institute of Freshwater Aquaculture, Bhubaneswar, India for provision of facilities for the study.

\section{References}

APHA-AWWA-WPCF. Standard methods for the examination of water and wastewater. American Public Health Association, New York. 1989, 1-1193.

Bhatti MN, Qureshi TS. A note on the comparison of efficiency of Ovatide and Ovaprim on grass carp with reference to fecundity, fertilization and hatching at Fish Nursery Complex, Muzaffargarh. Pakistan Journal of Fisheries. 2000; 1(1):107.

Chakrabarti PP, Mohapatra BC, Ghosh A, Mandal SC, Majhi D, Jayasankar P. Seed production of Indian major and minor carps in FRP hatchery at Bali, a remote Island of Indian Sunderban. International Journal of Fisheries and Aquatic Studies. 2016; 4(4):31-34.

CIFE. New synthetic hormone "Ovatide" for fish breeding. Central Institute of Fisheries Education, Mumbai, India, 1997, 1-25.

Dhawan A, Kaur K. Comparative efficacy of Ovaprim and Ovatide in carp breeding. Indian Journal of Fisheries. 2004; 51(2):227-228.

FAO. The state of world fisheries and aquaculture: Contributing to food security and nutrition for all. Food and Agriculture Organization, Rome, 2016, 2.

Gupta SD, Mohapatra BC, Routray P, Sahoo SK, Verma DK, Sarangi N. Text Book of Breeding and Hatchery
Management of Carps. Narendra Publishing House, Delhi, 2008, 1-163.

Khan AM, Shakir HA, Ashraf M, Muhammad Z. Induced spawning of Labeo rohita using synthetic hormones. Punjab Univ. J Zool. 2006. 21(1-2):67-72.

Mohanty BB, Mal BC, Sharma KK, Mohapatra BC. Water requirements of a portable FRP carp hatchery-for rohu spawning and eggs hatching. Fishing Chimes. 2009; 29(5):47-49.

Mohapatra BC, Barik NK, Chakrabarti PP, Pillai BR and Sundaray JK. FRP carp hatchery in India: Adoption, impact and issues. ICAR-Central Institute of Freshwater Aquaculture, Bhubaneswar, 2017, 1-66.

Mohapatra BC, Barik NK, Udit UK. Area saturation model of freshwater aquaculture technology demonstration for livelihood development of tribal farmers of Niladriprasad Gram Panchayat of Banpur Block, Khordha District, Odisha. J. Natural Resources \& Development. 2018a; 13(1):18-26.

Mohapatra BC, Barik NK. Development of model village cluster for aquaculture: A case in Begunia Block of Khordha District, Odisha, India. International Journal of Fisheries and Aquatic Studies. 2018b; 6(2):534-540.

Mohapatra BC, Kedar Nath Mohanta and Dukhia Majhi. Indian major carps seed production through induced breeding in FRP hatchery at Bisoi, Mayurbhanj district, Odisha, India. International Journal of Fisheries and Aquatic Studies 2018c; 6(4): 492-496.

Mohapatra BC, Mahanta SK, Sahu H, Majhi D, Barik NK. Induced breeding of Indian major carps in FRP hatchery at farmer's field. International Research Journal of Natural and Applied Science. 2016; 3(5): 249-257.

Mohapatra BC, Mahanta SK, Sahu H, Mohanty UL, Rath DP, Majhi D et al., 
Induced breeding of Indian major carps in FRP hatchery in farmer's field at Subarnapur Village, Gop Block, Puri District, Odisha. Fishing Chimes 2015; 35(8):47-49, 51-52.

Mohapatra BC, Sarkar B, Singh SK. Use of plastics in aquaculture. In: Satapathy KK and Kumar A (ed.), Plasticulture intervention for agriculture development in North Eastern Region. ICAR Research Complex for NEH Region, Umiam, Meghalaya, 2003, 290-305.
Mohapatra BC, Singh SK, Sarkar B, Sarangi N. Portable FRP carp hatchery: An aid for rural aquaculture. Proceedings International Conference on Plasticulture and Precision Farming, November, New Delhi, India. 2005, 17- 21, 515-522.

Pandey AK, Mahaptra CT, Kanungo G, Sarkar M, Sahoo GC, Singh BN. Ovadite induced spawning in the Indian major carp, Labeo rohita (Hamilton-Buchanan). Aquaculture. $2002 ; 3: 1-4$.

\section{How to cite this article:}

Mohapatra, B. C., N. K. Moharana, D. Majhi, A. D. Sahu, M. Mahapatra and Bhoi, S. P. 2020. Carp Seed Production in FRP Hatcheries by Tribal Farmers of Ganjam District, Odisha, India. Int.J.Curr.Microbiol.App.Sci. 9(06): 3012-3021. doi: https://doi.org/10.20546/ijcmas.2020.906.362 